\title{
„TOTUS TUUS” ŚW. JANA PAWŁA II \\ OD TEOLOGICZNEJ GŁĘBI \\ PO IKONOGRAFICZNĄ MISTYFIKACJĘ
}

Życiowa dewiza Karola Wojtyły - papieża, św. Jana Pawła II - zawierała się w dwóch prostych słowach: Totus Tuus. Zaczerpnięte one zostały z pochodzącego z początku XVIII stulecia, a wydanego w 1843 roku Traktatu o prawdziwym nabożeństwie do Najświętszej Maryi Panny św. Ludwika Marii Grignion de Montfort. To motto zainspirowało krakowską artystkę Izabelę Delektę-Wicińską do namalowania wyjątkowego obrazu Totus Tuus (il. 1), który uzyskał nieprawdopodobną popularność w całym świecie, stając się przedmiotem pobożnościowego oszustwa.

\section{FUNDAMENTY}

Młody Karol Wojtyła, wcześnie osierocony przez rodzicielkę, w osobie Najświętszej Maryi Panny znalazł swą matkę i opiekunkę. Ona uczyła go wrażliwości, łagodności i dobroci. Pierwszym szczególnym miejscem kontaktu z Maryją w oparciu o nabożeństwo wyniesione $\mathrm{z}$ domu rodzinnego był wadowicki kościół parafialny, w którym czczono wizerunek Matki Boskiej Nieustającej Pomocy. To właśnie tam, przed Jej obrazem, Karol modlił się rano, spiesząc do szkoły; zaglądał tam również, wracając po odbytych lekcjach. Tak o tym sam wspominał: „Nabożeństwo do Matki Bożej w postaci tradycyjnej wyniosłem z domu rodzinnego i z parafii wadowickiej. W kościele parafialnym pamiętam boczną kaplicę Matki Bożej Nie-

Ks. prof. dr hab. Andrzej Witko, Katedra Historii Sztuki Nowożytnej, Instytut Historii Sztuki i Kultury, Uniwersytet Papieski Jana Pawła II w Krakowie; adres do korespondencji: ul. Sławkowska 32, 31-014 Kraków; e-mail: andrzej.witko@upjp2.edu.pl; ORCID: 0000-0002-8510-6757 
ustającej Pomocy, do której rano przed lekcjami ciągnęli gimnazjaliści. Potem z kolei w godzinach popołudniowych, po zakończonych lekcjach, ten sam pochód uczniów szedł do kościoła na modlitwę" (Jan Paweł II, Dar i tajemnica 28).

Drugim miejscem jego żywego kontaktu z Matką Bożą był wadowicki klasztor karmelitów bosych. Tam Karol, jeszcze w dzieciństwie, przyjął święty szkaplerz, który nosił przez całe życie, wierząc w obietnice przekazane czcicielom Maryi. Tak o tym pisał: „W Wadowicach był Karmel, klasztor na Górce, czasem swojego powstania związany z postacią św. Rafała Kalinowskiego. Wadowiczanie licznie uczęszczali do tego klasztoru, a to oznaczało związanie się z tradycją karmelitańskiego szkaplerza. Ja też zapisałem się do szkaplerza, mając chyba 10 lat, i do dzisiaj ten szkaplerz noszę. Do karmelitów chodziło się także do spowiedzi. Tak więc zarówno kościół parafialny, jak i klasztor na Górce kształtował moją pobożność maryjną, jako chłopca, a później młodzieńca i gimnazjalisty, aż do egzaminu dojrzałości" (28-29).

Trzeci element w duchowym fundamencie maryjnego nabożeństwa Karola Wojtyły związany był z sanktuarium Matki Bożej w Kalwarii Zebrzydowskiej, gdzie przybywał już w dzieciństwie wraz ze swym ojcem. Sanktuarium kalwaryjskie przynosiło wymowną lekcję pobożności przyszłego papieża, ucząc go właściwego nabożeństwa do Świętej Bożej Rodzicielki, która prowadzi do Chrystusa. Tak o tym wspominał:

To jest tradycja pielgrzymek do sanktuarium w Kalwarii Zebrzydowskiej, jednego z tych miejsc ściągających rzesze pielgrzymów, zwłaszcza z południowej Polski oraz z drugiej strony Karpat. To sanktuarium regionalne ma jeszcze jedną właściwość, mianowicie jest ono nie tylko maryjne, ale też i głęboko chrystocentryczne. Pielgrzymki zaś, które przybywają, w ciągu dni swego pobytu na Kalwarii przede wszystkim odbywają dróżki, a są one po prostu drogą krzyżowa, na której człowiek odnajduje swoje miejsce przy Chrystusie poprzez Maryję. Ukrzyżowanie jest też najwyższym punktem topograficznym, który dominuje nad całą okolicą sanktuarium. Uroczysta procesja maryjna poprzedzająca uroczystość Wniebowzięcia to nic innego, jak wyraz wiary ludu chrześcijańskiego w szczególny udział Maryi w zmartwychwstaniu i chwale własnego Syna. Od najmłodszych lat maryjność wiązała się więc dla mnie ściśle z wątkiem chrystologicznym. W tym kierunku wychowywało mnie właśnie kalwaryjskie sanktuarium (Jan Paweł II, Przekroczyć próg nadziei 158).

Gdy Karol Wojtyła zamieszkał w Krakowie na Dębnikach, wszedł w krąg żywego różańca w salezjańskiej parafii, co pogłębiło także jego nabożeństwo do Matki Bożej Wspomożycielki Wiernych. Właśnie wtedy, gdy zastanawiał się nad swoją przyszłością, przeżywał duże trudności w realizacji nabożeństwa maryjnego:

Na Dębnikach w okresie, w którym krystalizowała się sprawa mojego powołania kapłańskiego, a także pod wpływem osoby Jana Tyranowskiego, mój sposób pojmowania nabożeństwa do Matki Bożej uległ pewnej przebudowie. O ile dawniej byłem przekonany, że Maryja prowadzi nas do 
Chrystusa, to w tym okresie zacząłem rozumieć, że również i Chrystus prowadzi nas do swojej Matki. Był taki moment, kiedy nawet poniekąd zakwestionowałem swoją pobożność maryjną uważając, że posiada ona w sposób przesadny pierwszeństwo przed nabożeństwem do samego Chrystusa (Jan Paweł II, Dar i tajemnica 29).

I dopiero, jak sam wyznał, skutecznym wsparciem dlań okazała się lektura Traktatu o prawdziwym nabożeństwie do Najświętszej Maryi Panny św. Ludwika Marii Grignion de Montfort, który stał się drogowskazem jego pobożności maryjnej i zainspirował go do wyboru życiowej dewizy: Totus Tuus.

W homilii wygłoszonej w dwudziestą rocznicę swego pontyfikatu Jan Paweł II mówił z mocą:

\begin{abstract}
Mamy dziękować Bogu za opatrznościową troskę, z jaką nieustannie prowadzi i wspomaga swój lud na drogach historii; ja mam ponowić swoje tak ..., zawierzając łasce Bożej; wy ze swej strony macie ofiarować Bogu postanowienie nieustannej modlitwy za papieża, aby mógł do końca wypełnić swoją misję. Z całego serca ponawiam zawierzenie mego życia i posługi Maryi Pannie, Matce Odkupiciela i Matce Kościoła. Z synowskim oddaniem powtarzam Jej: Totus Tuus! (Homilia wygłoszona 18 października 1998 roku).
\end{abstract}

\title{
2. TRAKTAT ŚW. LUDWIKA MARII GRIGNION DE MONTFORT
}

Totus Tuus - dewiza Karola Wojtyły, a następnie papieża Jana Pawła II - wyrosła z głębokiego doświadczenia jego wiary. To życiowe motto było owocem jego dojrzewania w szkole Matki Bożej. Podstawową wykładnią dla przyszłego papieża stała się niepozorna książka, o czym sam Ojciec Święty Jan Paweł II tak mówił: „Z pomocą przyszła mi książeczka św. Ludwika Marii Grignion de Montfort, nosząca tytuł: Traktat o prawdziwym nabożeństwie do Najświętszej Maryi Panny (Dar i tajemnica 29).

Przyszły papież Polak w swej młodości żywił obawy, czy nabożeństwo maryjne nie przesłoni osoby Bożego Syna. Studium Traktatu o prawdziwym nabożeństwie nie tylko rozproszyło takie wątpliwości, ale nadto ukierunkowało pobożność Karola Wojtyły chrystocentrycznie. Ta postawa zaowocowała mottem życia Totus Tuus, o czym papież tak pisał: „Totus Tuus... Formuła ta nie ma tylko charakteru pobożnościowego, nie jest wyrazem tylko dewocji, lecz jest czymś więcej. Muszę dodać, że przekonanie do takiego właśnie nabożeństwa zrodziło się we mnie w okresie, gdy podczas drugiej wojny światowej pracowałem jako robotnik w fabryce. Przedtem zdawało mi się, że powinienem odsunąć się nieco od dziecięcej pobożności maryjnej na rzecz chrystocentryzmu. Dzięki św. Ludwikowi Grignion de Montfort zrozumiałem, że prawdziwe nabożeństwo do Matki Bożej jest właśnie chrysto- 
centryczne, co więcej, jest najgłębiej zakorzenione w Trynitarnej tajemnicy Boga, związane z misterium Wcielenia i Odkupienia" (Jan Paweł II, Przekroczyć próg nadziei 157).

Spotkanie z książką francuskiego teologa stało się doświadczeniem wyjątkowym w życiu młodego Karola. Czytał on ów tekst wielokrotnie „w ciągu wielu dni i tygodni”, jak sam mówił, „tam i z powrotem”. Była to tak wciągająca dlań lektura, zwłaszcza podczas pracy w krakowskim Solvayu, że książka pokryła się plamami. „Tak bardzo ją czytałem - wspomniał - że cała była poplamiona sodą - i na okładkach, i w środku. Pamiętam dobrze te plamy sody, bo są one ważnym elementem całego mojego życia wewnętrznego" (Wojtyła, Homilia w dniu Nawiedzenia Matki Bożej Jasnogórskiej [06.05.1968]).

Lektura Traktatu rozjaśniła wszelkie obawy i wątpliwości Karola Wojtyły:

W książeczce tej znalazłem poniekąd gotową odpowiedź na moje pytania. Tak, Maryja nas przybliża do Chrystusa, prowadzi nas do Niego, ale pod warunkiem, że przeżyjemy Jej tajemnicę w Chrystusie. Traktat św. Ludwika Marii Grignion de Montfort może razić swoim stylem przesadnym i barokowym, ale sam rdzeń prawd teologicznych, które w tym traktacie się zawierają, jest bezcenny. Autor jest teologiem wielkiej klasy. Jego myśl mariologiczna zakorzeniona jest w tajemnicy trynitarnej oraz w prawdzie o Wcieleniu Słowa Bożego (Jan Paweł II, Dar i tajemnica 30).

Kulminacyjnym punktem udziału Matki Bożej w zbawczym misterium Chrystusa jest Jej obecność pod krzyżem Syna na Kalwarii, szczegółowo opisana przez św. Jana w jego Ewangelii (J 19, 25-27). To właśnie wówczas Zbawiciel oddał nam Maryję za matkę, zawierzając Jej macierzyńskiej trosce losy rodzącego się Kościoła. Ojciec Święty w liście do rodzin montfortiańskich z roku 2003 związał ten biblijny opis $\mathrm{z}$ mottem swej posługi:

Jak wiadomo, inspiracją dewizy Totus Tuus, widniejącej na moim herbie, który w sposób symboliczny ilustruje cytowany wyżej tekst Ewangelii, była doktryna św. Ludwika Marii Grignion de Montfort. Te dwa słowa wyrażają całkowitą przynależność do Jezusa za pośrednictwem Maryi. Tuus totus ego sum, et omnia mea tua sunt - pisze św. Ludwik Maria i thumaczy to następujaco - Oto jestem caly Twój i wszystko, co moje, Twoim jest, o Jezu mój najmilszy, przez Maryję, Twa Najświętsza Matkę. Doktryna św. Ludwika Marii wywarła wielki wpływ na pobożność maryjną wielu wiernych i również na moje życie. Jest to nauka sprawdzona w życiu, o wielkiej głębi ascetycznej i mistycznej, wyrażona za pomocą żywego i płomiennego stylu, w którym często używa się obrazów i symboli. Od czasów św. Ludwika Marii nastąpił znaczny rozwój teologii maryjnej; przyczynił się do tego istotnie przede wszystkim Sobór Watykański II. Dlatego naukę montfortiańską należy dziś odczytywać i interpretować w świetle nauczania Soboru, przez co nie traci ona bynajmniej swej istotnej wartości (Do Braci i Sióstr z rodzin montfortiańskich 1; por. List apostolski „Rosarium Virginis Mariae” 15).

Tak niepozorna, i zdawać by się mogło banalna książeczka, legła u fundamentów wielkiego pontyfikatu polskiego papieża: „Tu thumaczy się pochodzenie owego Totus 
Tuus. Bierze ono początek właśnie od św. Ludwika Marii Grignion de Montfort. Jest właściwie skrótem pełniejszej formuły zawierzenia Matce Bożej, która brzmi: Totus Tuus ego sum et omnia mea tua sunt. Accipio te in mea omnia. Praebe mihi cor tuum, Maria" (Dar i tajemnica 30).

Dewiza apostolskiej posługi Jana Pawła II towarzyszyła mu nieprzerwanie. Na zakończenie swej ostatniej pielgrzymki do Polski w Kalwarii Zebrzydowskiej ponowił on swoje oddanie i zawierzenie w niezapomnianych słowach modlitwy:

Przeto, Orędowniczko nasza, one miłosierne oczy Twoje na nas zwróć, a Jezusa, błogosławiony Owoc żywota Twojego, po tym wygnaniu nam okaż. O łaskawa, o litościwa, o słodka Panno Maryjo! Wejrzyj, łaskawa Pani, na ten lud, który od wieków pozostawał wierny Tobie i Synowi Twemu. Wejrzyj na ten naród, który zawsze pokładał nadzieję w Twojej matczynej miłości. Wejrzyj, zwróć na nas swe miłosierne oczy, wypraszaj to, czego dzieci Twoje najbardziej potrzebują. Dla ubogich i cierpiących otwieraj serca zamożnych. Bezrobotnym daj spotkać pracodawcę. Wyrzucanym na bruk pomóż znaleźć dach nad głową. Rodzinom daj miłość, która pozwala przetrwać wszelkie trudności. Młodym pokazuj drogę i perspektywy na przyszłość. Dzieci otocz płaszczem swej opieki, aby nie ulegały zgorszeniu. Wspólnoty zakonne ożywiaj łaską wiary, nadziei i miłości. Kapłanów ucz naśladować Twojego Syna w oddawaniu co dnia życia za owce. Biskupom upraszaj światło Ducha Świętego, aby prowadzili ten Kościół jedną i prostą drogą do bram Królestwa Twojego Syna. Matko Najświętsza, Pani Kalwaryjska, wypraszaj także i mnie siły ciała i ducha, abym wypełnił do końca misję, którą mi zlecił Zmartwychwstały. Tobie oddaję wszystkie owoce mego życia i posługi; Tobie zawierzam losy Kościoła; Tobie polecam mój naród; Tobie ufam i Tobie raz jeszcze wyznaję: Totus Tuus, Maria! Totus Tuus" (Homilia podczas Mszy św. z okazji 400-lecia sanktuarium w Kalwarii Zebrzydowskiej 5).

\section{ZNACZENIE}

Życiowe motto Karola Wojtyły - Jana Pawła II, Totus Tuus, było owocem medytacji nad Traktatem o prawdziwym nabożeństwie do Najświętszej Maryi Panny św. Ludwika Marii Grignion de Montfort. Ojciec Święty tak wspominał to doświadczenie:

Dzięki św. Ludwikowi zacząłem na nowo odkrywać wszystkie skarby dotychczasowej pobożności maryjnej, ale niejako z nowych pozycji: na przykład od dziecka słuchałem Godzinek o Niepokalanym Poczęciu Najświętszej Maryi Panny śpiewanych w kościele parafialnym, ale dopiero wówczas dostrzegłem, jakie bogactwo treści teologicznej oraz treści biblijnej jest w nich zawarte. To samo odnosi się poniekąd do pieśni ludowych, chociażby do polskich kolęd na Boże Narodzenie, Gorzkich Żalów na Wielki Post, w których osobne miejsce zajmuje dialog duszy z Matką Bolesną ... Zrozumiałem wówczas, dlaczego Kościół trzy razy w ciągu dnia odmawia Anioł Pański, zrozumiałem też, jak bardzo kluczowe są słowa tej modlitwy: Anioł Pański zwiastował Pannie Maryi i poczęła z Ducha Świętego... Oto ja stużebnica Pańska, niech mi się stanie wedtug stowa twego... ASłowostałosięciałemizamieszkało wśródnas ... Istotnie słowakluczowe! Wyrażająonezasadniczą treść największego wydarzenia, jakie dokonało się w dziejach ludzkości (Dar i tajemnica 31). 
Zainspirowany przez francuskiego teologa, przyszły papież bez obaw rozmiłował się w Maryi, kontemplując Jej postać „w świetle Słowa, które stało się człowiekiem” (Sobór Watykański II 65). Z ufnością podjął nabożeństwo do Matki Bożej, aby „Chrystusa tym doskonalej znaleźć, tym czulej ukochać i tym wierniej Mu służyć" (Ludwik Maria Grignion de Montfort, św. Traktat o prawdziwym nabożeństwie 62). Sam tak podsumował to doświadczenie:

\begin{abstract}
Nauczyłem się na nowo maryjności i ten dojrzały kształt nabożeństwa do Matki Bożej idzie ze mną od lat, a jego owocem jest zarówno encyklika Redemptoris Mater (Jan Paweł II, Encyklika „Redemptoris Mater”), jak i list apostolski Mulieris dignitatem (List apostolski „Mulieris dignitatem"). W odniesieniu do pobożności maryjnej każdy z nas musi być świadom, że nie chodzi tylko o potrzebę własnego serca, o pewną skłonność uczuciową, ale także o obiektywną prawdę o Bogarodzicy. Maryja jest nową Ewą, którą Bóg stawia wobec nowego Adama-Chrystusa, poczynając od Zwiastowania, poprzez noc betlejemskiego narodzenia, poprzez gody weselne w Kanie Galilejskiej, do krzyża na Golgocie, i z kolei do wieczernika Zielonych Świąt: Matka Chrystusa Odkupiciela jest Matką Kościoła. Sobór Watykański II jest tutaj krokiem milowym, zarówno, gdy chodzi o doktrynę, jak i nabożeństwo. Trudno cytować cały ten wspaniały VIII rozdział Lumen gentium, ale trzeba by tak uczynić. Uczestnicząc w Soborze, $w$ tym rozdziale rozpoznatem się w całej petni, odnalazłem wszystkie moje dawniejsze doświadczenia od lat młodzieńczych, odnalazłem też tę szczególną więź, jaka łączy mnie z Bogarodzicą w coraz to nowych wymiarach (Jan Paweł II, Przekroczyć próg nadziei 157-158).
\end{abstract}

Maryjność polskiego papieża znalazła swe streszczenie w wyborze dewizy życia, oznaczającej całkowite i bezgraniczne zawierzenie Matce Bożej, będące wyrazem jego żywej, konkretnej i ogarniającej wszystkie dziedziny życia wiary. Oddając się Jej - Matce Kościoła, która doznaje „czci jako najznakomitszy i całkiem szczególny członek Kościoła i jako jego typiczne wyobrażenie oraz najdoskonalszy wzorzec wiary i miłości” (Sobór Watykański II 53), przeżywał głęboką więź z Chrystusem. Z Maryją podejmował pielgrzymkę wiary, gdyż - jak napisał w liście apostolskim Novo millennio ineunte - „do Jezusa nie można dotrzeć inaczej jak tylko przez wiarę” (19). „Taka była właśnie droga, którą postępowała Maryja przez całe swe ziemskie życie, i jest to droga Kościoła pielgrzymującego aż do końca czasów" (Do Braci i Sióstr z rodzin montfortiańskich 7). Maryja, prowadząc nas w pielgrzymce wiary, „przyświeca Ludowi Bożemu pielgrzymującemu jako znak pewnej nadziei i pociechy" (Sobór Watykański II 68).

W maryjnym nabożeństwie papieża Polaka Częstochowa jawi się jako miejsce szczególnego jego zawierzenia Bogarodzicy, co sam tak wyjaśniał:

Osobny rozdział stanowi Jasna Góra ze swą Ikoną Czarnej Madonny. Dziewica Jasnogórska czczona jest od wieków jako Królowa Polski. Jest to sanktuarium całego Narodu. U swej Pani i Królowej Naród polski szukał przez wieki i szuka nadal oparcia i siły duchowego odrodzenia. Jest to miejsce szczególnej ewangelizacji. Wielkie wydarzenia w życiu Polski są zawsze jakoś 
z tym miejscem związane. Dawna i współczesna historia mojego Narodu właśnie tam, na Jasnej Górze, znajduje punkt swej szczególnej koncentracji. Myślę, że to, co powiedziałem, wystarczająco tłumaczy maryjną pobożność obecnego papieża, a nade wszystko jego postawę całkowitego zawierzenia Maryi - owo Totus Tuus (Przekroczyć próg nadziei 158).

To całkowite i bezgraniczne zawierzenie towarzyszyło Ojcu Świętemu przez całe jego życie. W przejmujących słowach kilkukrotnie odwoływał się on do tej dewizy w tekście swego testamentu:

Pragnę raz jeszcze całkowicie zdać się na Wolę Pana. On Sam zdecyduje, kiedy i jak mam zakończyć moje ziemskie życie i pasterzowanie. W życiu i śmierci Totus Tuus przez Niepokalaną. Przyjmując już teraz tę śmierć, ufam, że Chrystus da mi łaskę owego ostatniego Przejścia, czyli Paschy. Ufam też, że uczyni ją pożyteczną dla tej największej sprawy, której staram się służyć: dla zbawienia ludzi, dla ocalenia rodziny ludzkiej, a w niej wszystkich narodów i ludów (wśród nich serce w szczególny sposób się zwraca do mojej ziemskiej Ojczyzny), dla osób, które szczególnie mi powierzył - dla sprawy Kościoła, dla chwały Boga Samego ... Tym głębiej czuję, że znajduję się całkowicie w Bożych Rękach - i pozostaję nadal do dyspozycji mojego Pana, powierzając się Mu w Jego Niepokalanej Matce Totus Tuus (Testament).

\section{NIEZWYKŁY OBRAZ}

W roku $1984^{1}$ Izabela Delekta-Wicińska namalowała niezwykły obraz Totus Tuus $(100$ x $80 \mathrm{~cm})$, który stał się przedmiotem jednej z największych artystycznych mistyfikacji związanych z osobą papieża Jana Pawła II (Izabela Delekta-Wicińska 17).

Artystka, najczęściej podpisująca swe dzieła jako Iza Delekta-Wicińska, urodziła się w 1921 roku w Wadowicach, a więc zaledwie kilka miesięcy po przyjściu na świat w tym samym mieście Karola Wojtyły. Była córką kapitana 20. Pułku Piechoty Ziemi Krakowskiej i nauczycielki. W czasie drugiej wojny światowej uczyła się w Szkole Przemysłu Artystycznego, a równocześnie występowała w teatrach podziemnych Wiesława Góreckiego i Andrzeja Mularczyka. Już w 1945 roku rozpoczęła studia w krakowskiej Akademii Sztuk Pięknych, pod kierunkiem Zbigniewa Pronaszki, Wojciecha Weissa oraz Wacława Taranczewskiego, w którego pracowni uzyskała w 1952 roku dyplom. Równocześnie ukończyła studia aktorskie. Kilka lat poświęciła na naukę tańca pod kierunkiem Janiny Strzembosz i śpiewu u Bronisława Romaniszyna. Całe życie aktorskie związała ze słynnym teatrem Krakowa, od 1949 roku noszącym nazwę Państwowy Teatr Młodego Widza, przemianowanym w 1957 roku na Teatr Rozmaitości, a od 1970 roku noszącym pierwotną nazwę: Bagatela. Pozostawiła po sobie sześćdziesiąt sześć niezapomnianych kreacji aktorskich.

\footnotetext{
${ }^{1}$ Anna Steliga, nie wiadomo dlaczego, podaje 1986 jako rok powstania malowidła (150).
} 


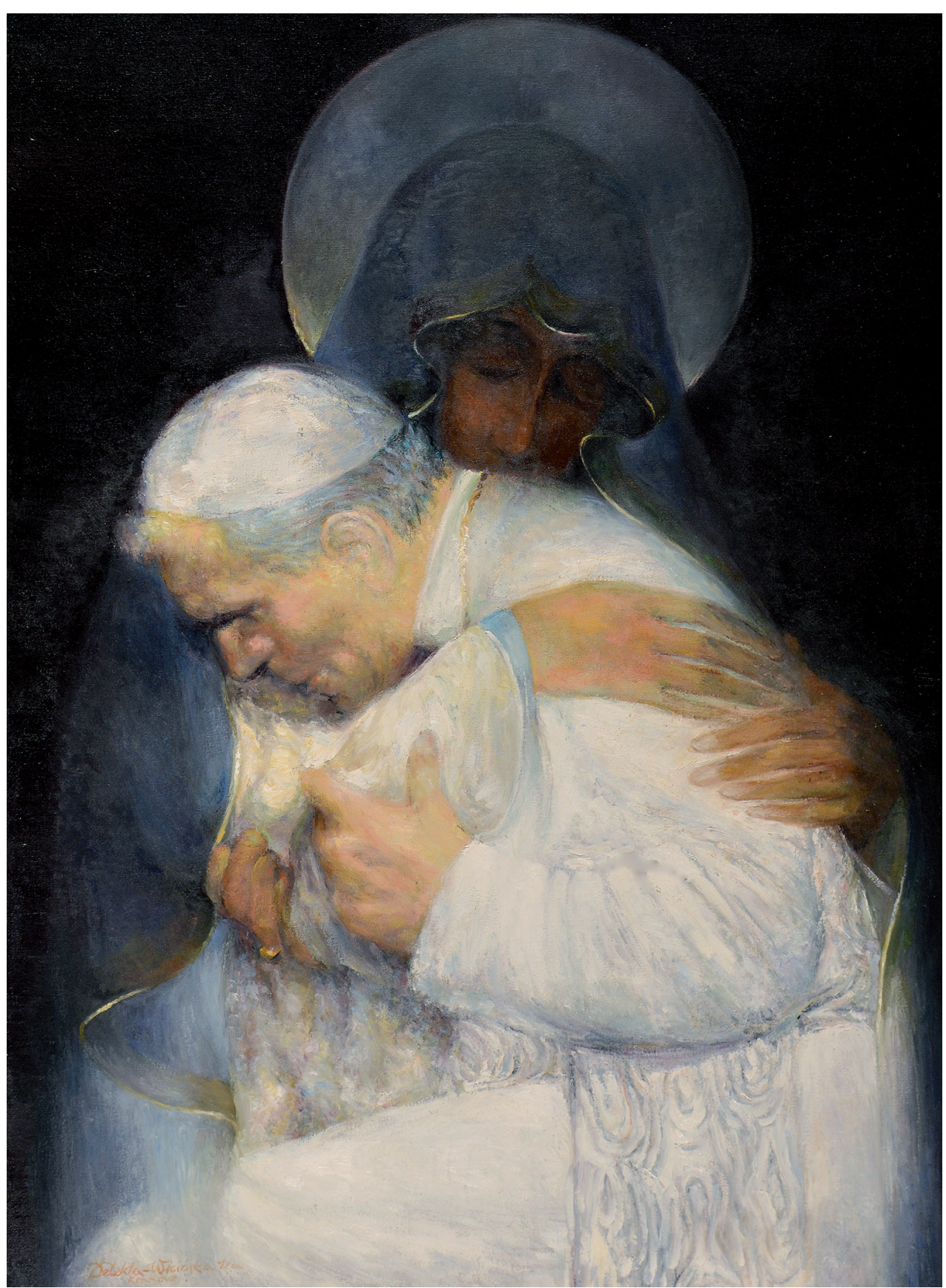

Izabela Delekta-Wicińska, Totus Tuus, olej na płótnie, Kraków, Towarzystwo Przyjaciół Sztuk Pięknych, fot. T. Śliwiński, Muzeum Archidiecezjalne w Krakowie 
Od 1949 roku równolegle prowadziła ożywioną działalność malarską, początkowo jako plastyk pracujący dla prasy, a od 1950 tworząc i wystawiając w wielu galeriach i muzeach. Artystka została odznaczona Złotym Krzyżem Zasługi, Złotą Odznaką Miasta Krakowa oraz Medalem za zasługi dla Marynistyki Polskiej (Witek 29).

W swoim przejmującym dziele Totus Tuus malarka przedstawiła Jana Pawła II w mistycznym uścisku z Matką Boską. Madonna, której rysy przywołują cudowny obraz jasnogórski, okryta jest błękitnym maforionem ze złotą lamówką. Obiema rękoma tuli do siebie polskiego papieża, ubranego w białą przepasaną sutannę, z głową nakrytą papieską piuską. Artystka, jak sama opowiedziała o tym piszącemu te słowa, zainspirowała się niezwykłym uściskiem Jana Pawła II i kard. Stefana Wyszyńskiego w dniu inauguracji pontyfikatu polskiego papieża, 22 października 1978 roku. Ten właśnie moment natchnął także prof. Jerzego Jarnuszkiewicza - twórcę słynnego pomnika Jana Pawła II i kard. Stefana Wyszyńskiego na dziedzińcu Katolickiego Uniwersytetu Lubelskiego. Malowidło krakowskiej artystki zyskało znakomite recenzje, a jego odbitki fotograficzne, rozpowszechniane nie tylko przez katolickie wydawnictwa, cieszyły się wielką popularnością.

W niedługim czasie fotografie obrazu Totus Tuus, najczęściej bardzo kiepskiej jakości, zaczęto upowszechniać w całym chrześcijańskim świecie jako cudowne zdjęcie. Wyprodukowano szereg niezwykłych teorii o powstaniu tej fotografii, którą uznano za nadprzyrodzoną. Jedna z nich mówiła, iż w czasie niezapomnianej audiencji generalnej 13 maja 1981 roku, podczas której dokonano zamachu na papieża Jana Pawła II, ktoś wykonał zdjęcie Ojca Świętego. Gdy wywołano kliszę, ze zdumieniem znaleziono na niej cudowne zdjęcie papieża $w$ ramionach Madonny. Inna wersja mówiła, iż jakaś Holenderka sfotografowała podczas swej podróży do Rzymu wirujące słońce, a po powiększeniu fotografii otrzymano cudowne zdjęcie Jana Pawła II w ramionach Matki Najświętszej. To przedstawienie stało się na początku lat dziewięćdziesiątych ubiegłego wieku jedną z najbardziej pożądanych fotografii, stanowiących, jak wierzono, nadprzyrodzone udokumentowanie bliskości polskiego papieża z Najświętszą Maryją Panną. Jako wyjątkowe zdjęcie rozpowszechniano je w Ameryce, Europie i Australii, a pielgrzymi w Medjugorje bez wahania płacili za słabą odbitkę po pięć marek niemieckich. Cudowna fotografia została opublikowana w kilku bardzo popularnych gazetach, m.in. w Stella Maris i Echu Medjugorja.

Nietrudno sobie wyobrazić, iż wiadomość o cudownym zdjęciu szybko dotarła do Krakowa, gdzie obraz krakowskiej malarki był dobrze znany. Środowisko artystyczne podejrzało, iż to sama Delekta-Wicińska, chcąc wzbudzić większe zainteresowanie swym dziełem, przyczyniła się do rozpowszechnienia fałszywej informacji o powstaniu cudownej fotografii, by czerpać zyski z masowo powielanych zdjęć. Były to absurdalne oskarżenia, gdyż Bogu ducha winna artystka nawet nie miała 
pojęcia, iż sprawa przybrała ogólnoświatowy wymiar. Wiele razy mocno podkreślała, że nie miała z całą mistyfikacją nic wspólnego. Choć bez wątpienia owo pobożnościowe oszustwo sprawiło, iż dzieło Totus Tuus stało się jednym z najpopularniejszych w ikonografii Jana Pawła II, pociągając za sobą powstanie wielu kopii wykonanych na płótnie, w rzeźbie czy w witrażu.

Sprawą zainteresował się nawet jeden z najwybitniejszych ówczesnych mariologów, ks. René Laurentin, który w czerwcu 1994 roku na łamach Chrétiens Magazine dedykował wyjątkowej papieskiej fotografii swój artykuł „Cudowne zdjęcie czy natchniony obraz?". Tekst ten z bardzo krytycznym komentarzem został przedrukowany w języku polskim na łamach Vox Domini jeszcze w 1994 roku, gdzie przywołano także fragmenty listu Izabeli Delekty-Wicińskiej na temat zaistniałej sytuacji:

Co jakiś czas od osób świeckich i duchownych otrzymuję dowody na to, co dzieje się za granicą, a co robi się z moją pracą. Jestem bezsilna!... Wiadomość o zainteresowaniu ks. Laurentina jest dla mnie pociechą, że wreszcie kogoś zaniepokoiło zło, trwające już od dobrych paru lat... To jest obraz, a nie żadna wizja. Wizerunek Matki Boskiej i ukochanego przeze mnie Ojca Świętego, który był częstym gościem mojego rodzinnego domu (Laurentin 8-9).

Oryginalny obraz Izy Delekty-Wicińskiej został poświęcony przez ks. Kardynała Stanisława Dziwisza 30 marca 2006 roku. Z okazji beatyfikacji Jana Pawła II w 2011 roku pięciu parafianom ofiarowano kopie malowidła Totus Tuus. Autorka, po powstaniu oryginału, kilkakrotnie wykonała repliki swego dzieła, jedną z nich przekazując św. Janowi Pawłowi II, inną Towarzystwu Przyjaciół Sztuk Pięknych w Krakowie. Kilka lat temu oryginał malowidła został zakupiony przez prywatnego kolekcjonera w województwie świętokrzyskim i dziś pozostaje niedostępny. Jeszcze w 2018 roku na stronie internetowej www.infovaticana.com podano wyjaśnienia, iż przedstawienie Totus Tuus nie jest cudowną fotografią św. Jana Pawła II, ale malarską wizją krakowskiej artystki Izabeli Delekty-Wicińskiej (¿Es auténtica la imagen "viral" de Juan Pablo II?).

\section{BIBLIOGRAFIA}

¿Es auténtica la imagen "viral” de Juan Pablo II y la Virgen?, 2018, infovaticana.com/2018/07/23/ es-autentica-la-imagen-viral-de-juan-pablo-ii-y-la-virgen/. Dostęp 15.12.2019.

Izabela Delekta-Wicińska. Obrazy, red. Przemysław J. Witek. Towarzystwo Przyjaciół Sztuk Pięknych w Krakowie, 2004.

JAN PAwEe II, św. Dar i tajemnica. Wydawnictwo św. Stanisława B.M., 1996.

JAN PAwel II, św. Do Braci i Sióstr z rodzin montfortiańskich, Rzym 2003, www.zyciezakonne.p1/dokumenty/kosciol/jan-pawel-ii/jan-pawel-ii-listy-i-przeslania/2003-12-08-watykan-list-papieski-do-rodzin-montfortianskich-20029/. Dostęp 15.12.2019. 
JAN PAwel II, św. Encyklika „, Redemptoris Mater” o blogosławionej Maryi Dziewicy w życiu pielgrzymującego Kościoła, Rzym 1987, opoka.org.pl/biblioteka/W/WP/jan_pawel_ii/encykliki/r_mater_1.html. Dostęp 15.12.2019.

JAN PAWEe II, św. Homilia podczas Mszy św. z okazji 400-lecia sanktuarium w Kalwarii Zebrzydowskiej, opoka.org.pl/biblioteka/W/WP/jan_pawel_ii/homilie/8pl_kalwaria_19082002.html. Dostęp 15.12.2019.

JAN PAWeŁ II, św. Homilia wygłoszona 18 października 1998 roku w dwudziesta rocznice pontyfikatu, opoka.org.pl/biblioteka/W/WP/jan_pawel_ii/homilie/msza_18101998.html. Dostęp 15.12.2019.

JAN PAWEe II, św. List apostolski „, Mulieris dignitatem” z okazji Roku Maryjnego o godności i powotaniu kobiety, Rzym 1988, opoka.org.pl/biblioteka/W/WP/jan_pawel_ii/listy/mulieris.html. Dostęp 15.12.2019.

JAN PAwEe II, św. List apostolski , Novo millennio ineunte”, www.vatican.va/content/john-paul-ii/ pl/apost_letters/2001/documents/hf_jp-ii_apl_20010106_novo-millennio-ineunte.html. Dostęp 15.12.2019.

JAN PAweŁ II, św. List apostolski „Rosarium Virginis Mariae” o różańcu świętym. Rzym 2002, www. vatican.va/content/john-paul-ii/pl/apost_letters/2002/documents/hf_jp-ii_apl_20021016_rosarium-virginis-mariae.html. Dostęp 15.12.2019.

JAN PAWEŁ II, św. Przekroczyć próg nadziei. Redakcja Wydawnictw Katolickiego Uniwersytetu Lubelskiego, 1994. Dostęp 15.12.2019

JAN PAWEŁ II, św. Testament, opoka.org.pl/biblioteka/W/WP/jan_pawel_ii/inne/testament_ jp2_20050407.html. Dostęp 15.12.2019.

Laurentin, René. „Cudowne zdjęcie czy natchniony obraz?”. Vox Domini, nr 3, 1994, ss. 8-9.

Ludwik Maria Grignion de Montfort, św. Traktat o prawdziwym nabożeństwie do Najświętszej Maryi Panny. Tłum. Jerzy Rybałt. Wyd. 3, Zgromadzenie Księży Marianów, 1986.

Sовór WaTyKaŃSKI II. Konstytucja dogmatyczna o Kościele „Lumen gentium”. Wrocławska Księgarnia Archidiecezjalna, 1986.

Steliga, Anna. „Nie budujcie mi pomników. Wizja Świętego Jana Pawła II w sztuce sakralnej”. Dydaktyka Polonistyczna, t. 11, nr 2, 2016, ss. 148-161.

WITEK, Zbigniew Kazimierz. „Izabela Delekta-Wicińska”. Kolekcja malarstwa z przełomu XX i XXI wieku artystów krakowskich. Towarzystwo Przyjaciół Sztuk Pięknych w Krakowie, 2016, ss. 29-32.

WojtyŁa, Karol. „Homilia w dniu Nawiedzenia Matki Bożej Jasnogórskiej (06.05.1968) w parafii Matki Boskiej Zwycięskiej w Borku Fałęckim”, www.katolicki.net/index.php/parafia-karol-woltyla.html. Dostęp 15.12.2019.

\section{„TOTUS TUUS” ŚW. JANA PAWŁA II \\ OD TEOLOGICZNEJ GŁĘBI PO IKONOGRAFICZNĄ MISTYFIKACJĘ}

Streszczenie

Życiowa dewiza Karola Wojtyły - papieża św. Jana Pawła II zawierała się w dwóch słowach: Totus Tuus. Zaczerpnięte one zostały z pochodzącego z początku XVIII stulecia, a wydanego w 1843 roku Traktatu o prawdziwym nabożeństwie do Najświętszej Maryi Panny św. Ludwika Marii Grignion de Montfort. Wybór takiego motta życia wyrażał całkowite i bezgraniczne zawierzenie się Matce Bożej przez Jej wyjątkowego czciciela, będąc wyrazem jego żywej, konkretnej i ogarniającej wszystkie dziedziny życia wiary. Ta właśnie dewiza zainspirowała krakowską artystkę Izabelę Delektę-Wicińską do namalowania w roku 1984 wyjątkowego obrazu Totus Tuus, który uzyskał nieprawdopodobną popularność w świecie, stając się przedmiotem pobożnościowego oszustwa. Choć artystka utrzymywała, że zainspirowała się niezwykłym uściskiem Jana Pawła II i kard. Stefana Wyszyńskiego w dniu inaugu- 
racji pontyfikatu polskiego papieża, jednak fotografie malowidła Totus Tuus zaczęto rozpowszechniać w całym chrześcijańskim świecie jako cudowne zdjęcie, przypadkowo wykonane papieżowi Janowi Pawłowi II. Na początku lat dziewięćdziesiątych XX wieku sprawą zainteresowano nawet jednego z najwybitniejszych ówczesnych mariologów - ks. René Laurentina. Jeszcze w 2018 roku na stronie internetowej www.infovaticana.com podano wyjaśnienia, iż przedstawienie Totus Tuus nie jest cudowną fotografią św. Jana Pawła II, ale malarską wizją krakowskiej artystki - Izabeli Delekty-Wicińskiej.

Słowa kluczowe: św. Jan Paweł II; św. Ludwik Maria Grignion de Montfort; Izabela DelektaWicińska; René Laurentin; Totus Tuus.

\section{„TOTUS TUUS” BY SAINT JOHN PAUL II. FROM THEOLOGICAL DEPTH TO ICONOGRAPHICAL MYSTIFICATION}

\section{Sum mary}

The life motto of Karol Wojtyła - of the Pope St John Paul II - was contained in two words: Totus Tuus. They were derived from the work dating back to the $18^{\text {th }}$ century and published in 1843: Treatise on True Devotion to the Blessed Virgin Mary by St Louis Marie Grignion de Montfort. The choice of such a life's motto was expressing the total and limitless offering of the exceptional follower to the Mother of God, also being an expression of his living, concrete, overwhelming and all-encompassing faith. This very motto has inspired Izabela Delekta-Wicińska, a Cracovian artist, to paint - in the year 1984 - a unique picture Totus Tuus, which gained enormous popularity in the whole world, thus becoming an object of fraud in respect of piety. Even though the artist held that she was inspired by an exceptional embrace of John Paul II and Cardinal Stefan Wyszyński on the day of inauguration of the pontificate of the Polish Pope, a photograph of the Totus Tuus painting was circulated in the entire Christian world as a miraculous picture of Pope John Paul II that was taken accidentally. In the early 1990s one of the then most pre-eminent mariologists, Rev. René Laurentin, was interested in the matter. Even as late as in the 2018 the www.infovaticana.com website explained that the Totus Tuus depiction is not a miraculous photography of the St. John Paul II but a painterly vision of the Cracovian artist, Izabela Delekta-Wicińska.

Translated by Marta A. Urbańska

Keywords: St John Paul II; St Louis Marie Grignion de Montfort; Izabela Delekta-Wicińska; René Laurentin; Totus Tuus. 